\title{
Highly Specific Bacteriophage-associated Polysaccharide Hydrolases for Klebsiella aerogenes type 8
}

\author{
By I. W. SUTHERLAND \\ Department of Microbiology, University of Edinburgh, Edinburgh EH9 ${ }_{3} J G$
}

(Received 23 June 1975; revised 10 November 1975)

\begin{abstract}
SUMMARY
Two phage-bound polysaccharide hydrolases specific for Klebsiella aerogenes type 8 exopolysaccharides were isolated. Each enzyme was specific for the polysaccharide produced by the host strain. One enzyme hydrolysed a pyruvylated and acetylated polymer, while the other only acted on the substrate lacking these substituents. Both enzymes were endogalactosidases releasing tetrasaccharides from their substrates which were only hydrolysed to a limited extent.
\end{abstract}

\section{INTRODUCTION}

Although Kauffmann \& Vahlne (I945) considered that capsulate bacteria were generally phage resistant, bacteriophages can be isolated for many capsulate species of bacteria. In many systems which have been studied, the typical plaque morphology consists of a large, clear plaque surrounded by a crater-like depression or halo in the bacterial lawn (see, for example, Eklund \& Wyss, 1962; Stirm, 1968). The halo comprises an area in which polysaccharide depolymerases induced in phage-infected bacteria remove or destroy capsular material without affecting bacterial viability. The polysaccharide depolymerases have been widely recognized and the nature and mode of action of the enzymes have been characterized in such diverse bacteria as Azotobacter vinelandii (Eklund \& Wyss, 1962), Escherichia coli (Sutherland, 197I), and various Klebsiella aerogenes serotypes (Bessler et al., I973; Sutherland \& Wilkinson, 1968). In the Azotobacter vinelandii and similar systems, the enzyme is normally present in two forms: as a soluble protein, and as a component of the bacteriophage particles. Both forms are apparently similar in their enzymic and other properties (Yurewicz et al., 1971). The enzyme may be equally distributed between these two forms as suggested by Adams \& Park (1956) for $K$. aerogenes type 2 phage enzyme systems. In other capsulate bacteria, even though the capsule occludes the whole bacterial surface, virulent phage can infect and lyse the bacteria, forming normal plaques without any haloes. This may be due to the presence of polysaccharide depolymerases entirely in the phagebound form.

This study presents evidence for the presence of small amounts of polysaccharide hydrolases (endoglycosidases) associated with the viral particles of two phages infecting distinct strains of $K$. aerogenes type 8 ; both bacteriophages form plaques without haloes.

\section{METHODS}

Bacteria and bacteriophages. Klebsiella aerogenes strain A4 (type 8) was used in an earlier study (Sutherland, 1970), and the structure of its exopolysaccharide is known. Strain 8s, also serotype 8, was obtained from Dr Hermann, Communicable Disease Center, 
Atlanta, Georgia, U.S.A. Both strains were maintained on nutrient agar slopes in screw-capped vials. Polysaccharide was prepared from cultures on nitrogen-deficient medium and purified according to the method of Dudman \& Wilkinson (1956). Virulent bacteriophages specific for each strain were isolated from local sewage using standard techniques, grown up from single plaque isolates and checked for purity of plaque type. Attempts to obtain polysaccharide depolymerases from phage-induced lysates of the host bacteria in the manner described (Sutherland \& Wilkinson, 1968) for other $K$. aerogenes strains and phages were unsuccessful. Large-scale preparations of phage were made using the soft agar layer technique. Bacterial debris and other material were removed by low-speed centrifuging, and the bacteriophages were recovered by centrifuging at $50000 \mathrm{~g}$ for $45 \mathrm{~min}$ in a MSE (London) ultracentrifuge with swing-out head. The phages were then resuspended aseptically in water at a protein concentration of $10 \mathrm{mg} \mathrm{ml}^{-1}$ and stored at $4{ }^{\circ} \mathrm{C}$.

Analytical techniques. Neutral sugars were estimated after enzymic hydrolysis of the polysaccharides or after hydrolysis with $0.5 \mathrm{M}-\mathrm{H}_{2} \mathrm{SO}_{4}$ for $16 \mathrm{~h}$ at $100{ }^{\circ} \mathrm{C}$ and neutralization with Amberlite IR 410 resin in the $\mathrm{HCO}_{3}^{-}$form. Glucose and galactose were determined using micromodifications of the respective oxidase-based reagents (Boehringer und Soehne, Mannheim, Germany, and Worthington Biochemicals, Freehold, New Jersey, U.S.A., respectively). Glucuronic acid was assayed by the modified carbazole reaction of Bitter \& Muir (1962). The techniques of Hestrin (1949) and Sloneker \& Orentas (I962) were used to test for $O$-acetyl groups and pyruvate respectively. Formate was determined by a micromodification of the method of Grant (1948), and protein was measured by the Folin technique (Lowry et al., 195I).

Enzymes. $\alpha$-Galactosidase and $\beta$-galactosidase were from Boehringer und Soehne, and $\beta$-glucosidase was from BDH.

Chromatography and electrophoresis. The chromatographic solvents used were: A, ethyl acetate-acetic acid-formic acid-water (18:3:1:4, by vol.); B, ethyl acetate-pyridineacetic acid-water (5:5:I:3, by vol.); and C, butan-I-ol-acetic acid-water ( $4: 1: 5$, by vol.) Descending paper chromatography was used with irrigation times of $36 \mathrm{~h}$, I6 h and $96 \mathrm{~h}$ respectively. Paper electrophoresis was performed in pyridinium acetate buffer (pyridineacetic acid-water; 5:2:43, by vol.) using a Locarte (London) apparatus.

\section{RESULTS}

\section{Phage host range}

Each of the phages was apparently specific for the bacterial host strain on which it was isolated. Attempts to obtain lysis of other mucoid $K$. aerogenes strains (of different serotypes) were unsuccessful. Phage sensitivities of non-mucoid mutants of either host strain were variable. Some A4 mutants were sensitive to one or other phage or were resistant to both. This was also true of mutants of the $8 \mathrm{~s}$ strain. There was thus no absolute requirement for capsular material on the bacterial host.

\section{Composition of the exopolysaccharides}

Using the type 8, A4 strain, the structure of $K$. aerogenes type 8 capsular polysaccharide was found to be a polymer with the tetrasaccharide repeating unit shown in Fig. I (Sutherland, 1970). It contained D-glucose, D-galactose and D-glucuronic acid in the molar ratio I:2:I. Acyl groups were apparently absent from the polymer. The exopolysaccharide from a further strain $(8 \mathrm{~s})$ of the same serotype contained the same monosaccharides in the same molar ratio, but, in addition, one mole of acetate and one mole of pyruvate per 


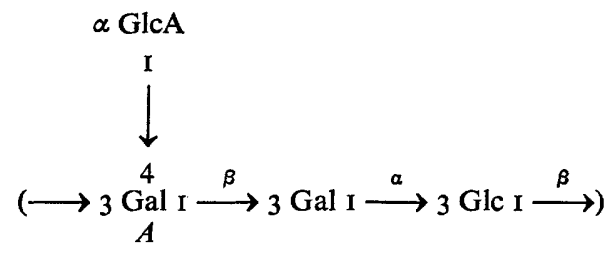

Fig. I. The structure of Klebsiella aerogenes type 8 exopolysaccharide. Gal, galactose; Glc, glucose; GlcA, glucuronic acid.

Table I. The composition of Klebsiella type 8 polysaccharides

Each analysis was performed in triplicate on three separate samples of polysaccharide.

$\begin{array}{ccccccc}\text { Composition (\% dry wt) } \\ \text { Strain } & \overbrace{\text { D-Glucose }}^{\text {Glucuronic }} & \text { D-Galactose } & \text { acid } & \text { Acetate } & \text { Pyruvate } & \text { Formate } \\ \text { A4 } & 23.0 & 47.0 & 21 \cdot 0 & 0.0 & 0.0 & 0 \\ \text { 8S } & 21.6 & 44.2 & 22.7 & 6.0 & 5.8 & 0\end{array}$

repeating unit were detected (Table $\mathrm{I}$ ). On the basis of partial acid hydrolysis and of periodate oxidation, the polymers from both strains appear to have essentially the same carbohydrate structure. On partial acid hydrolysis, the material from the $8 \mathrm{~s}$ strain yielded, in addition to the same series of oligosaccharides as the A4 strain, several pyruvylated fragments in amounts too small to permit satisfactory characterization. Formate was absent from both polysaccharides.

\section{Incubation of phage with polysaccharides}

On incubation of either 44 or $8 \mathrm{~s}$ exopolysaccharide with the homologous phage, the viscosity of the polysaccharide solutions fell markedly. No such effect was observed when A4 polysaccharide was incubated with $8 \mathrm{~s}$ phage or vice versa. After prolonged incubation at $35{ }^{\circ} \mathrm{C}$ or at room temperature, in the presence of azide or toluene to prevent bacterial growth, the addition of cold $\left(-20^{\circ} \mathrm{C}\right)$ acetone $(2$ vols.) to the mixtures precipitated unaltered polysaccharide. This amounted to $70-80 \%$ by weight of the original polysaccharide present. The presence of increased amounts of bacteriophage only caused a slight $(5-10 \%)$ further drop in the amount of acetone-precipitable material in each mixture.

The acetone-soluble material was concentrated under reduced pressure, and subjected to paper electrophoresis. A single strip of material, that was stained by alkaline silver nitrate, was obtained from each preparation. This material was then subjected to paper electrophoresis on a preparative scale, eluted from the paper and concentrated under vacuum to yield two preparations designated $\mathrm{F}_{4}$ and $\mathrm{F} 8$, from the $\mathrm{A} 4$ and 8 s polysaccharides respectively.

\section{Characterization of products of phage-treated polysaccharide}

Analysis of the two fractions, $\mathrm{F}_{4}$ and $\mathrm{F} 8$, by paper chromatography showed that they were free from contaminating material (Table 2): each behaved as a single component in several chromatographic solvents, while micro-analysis indicated that they were composed of the same monosaccharides in the same molar ratio as were the initial polysaccharides. In addition F8 contained equimolar amounts of acetate and pyruvate. Neither fraction contained formate. Treatment of both oligosaccharides with sodium borohydride converted 
Table 2. The properties of oligosaccharides from Klebsiella type 8 polysaccharides

\begin{tabular}{cllcccc} 
Oligo- & & & \multicolumn{3}{c}{$R_{\text {Glc }}$ in solvent } \\
saccharide & \multicolumn{1}{c}{ Components } & Molar ratio & $M_{\text {GlcA }}$ & A & B & C \\
F4 & Glc, Gal, GlcA & I:2:I & 0.40 & 0.13 & 0.08 & 0.02 \\
F8 & Glc, Gal, GlcA, Acetate, & I:2:I:I:I & 0.60 & 0.23 & 0.17 & 0.03 \\
& Pyruvate & I:I:I & 0.43 & 0.43 & 0.12 & 0.03 \\
F4G & Glc, Gal, GlcA & I:I:I & 0.44 & 0.20 & $0.1 \mathrm{I}$ & 0.08
\end{tabular}

approximately $50 \%$ of the galactose in each to galactitol. Thus both contained galactose as the terminal reducing sugar. The known structure of the original polymers indicates two galactose residues in the linear chain of the molecules. Either of these could have been reduced, depending on which linkages were hydrolysed by the phage preparations. If residue $A$ (Fig. I) were involved, the fragments should also contain a galactose molecule as the terminal non-reducing monosaccharide. Accordingly, oligosaccharides $\mathrm{F}_{4}$ and $\mathrm{F} 8$ were each incubated with $\alpha$-galactosidase and with $\beta$-galactosidase for $\mathrm{I} 6 \mathrm{~h}$ at $35^{\circ} \mathrm{C}$ under conditions in which equimolar amounts of melibiose and of lactose respectively were hydrolysed. Toluene was added to prevent bacterial growth.

The enzyme $\beta$-galactosidase did not release galactose from either oligosaccharide, but $\alpha$-galactosidase released approximately $26 \%$ of the total galactose from oligosaccharide $\mathrm{F} 4$. Thus almost $52 \%$ of this tetrasaccharide was converted to a trisaccharide. Prolonged incubation increased the yield of trisaccharide, designated $\mathrm{F}_{4} \mathrm{G}$, to approximately $90 \%$ of the total available. No galactose was obtained from oligosaccharide F8, by treatment with $\alpha$-galactosidase.

The trisaccharide $\mathrm{F}_{4} \mathrm{G}$ was expected to be identical with $O-\beta$-D-glucosyl(glucuronosyl)galactose obtained earlier from type 8 polysaccharide by partial acid hydrolysis (Sutherland, 1970). However, a direct comparison of this trisaccharide ( $\left.E_{3}\right)$ by paper electrophoresis and paper chromatography showed that the two oligosaccharides were not identical (Table 2). Further, $\beta$-glucosidase, which converted the trisaccharide $\mathrm{E}_{3}$ to equimolar amounts of glucose and $\alpha$-D-glucuronosyl-D-galactose, was inactive on $\mathrm{F}_{4} \mathrm{G}$. The resistance to $\beta$-glucosidase and the chromatographic and electrophoretic mobilities of the trisaccharide $\mathrm{F}_{4} \mathrm{G}$ cannot be explained on the basis of the known aspects of its structure. No tetrasaccharide for comparison with $\mathrm{F}_{4}$ can be obtained by partial acid hydrolysis of the A4 polysaccharide because of the extreme lability of the D-galactosyl-I $\rightarrow 3$-glucose portion of the molecule to acid hydrolysis (Sutherland, 1970).

Modification of the substrate polysaccharides by carboxyl reduction or by periodate oxidation altered the configurations enough to render them insusceptible to enzyme action.

\section{DISCUSSION}

Although many polysaccharide depolymerases associated with bacteriophages have now been recognized, most have been studied in a soluble form isolated from bacterial lysates. The enzymes have included endogalactosidases (Yurewicz et al., 1971), endofucosidases (Sutherland, I97I) and a polymannuronate eliminase (I. W. Davidson and I. W. Sutherland, unpublished results). More recently, Stirm and his colleagues have recognized that 'spikes' observed on the tails of certain phage particles were the phage-bound forms of several endoglycosidases (Stirm \& Freund-Moelbert, 197 I ; Bessler et al., 1973). The phage- 
bound enzymes reported in the present study may be of this type, although their location on the viral particles has not yet been unequivocally identified. The apparent absence of soluble enzymes in such phage-induced systems has not been commonly reported, but may be more frequent than hitherto recognized. As definitive studies (e.g. Yurewicz et al., 197I) indicate that soluble and phage-bound polysaccharide depolymerases are similar in their properties, the presence of soluble enzyme may merely indicate overproduction of one gene product controlled by the phage genome. Phages yielding entirely viral-bound enzyme may control the yield of enzyme more strictly and limit it to an amount comparable in phageequivalents to other components of the viral particles.

The specificity of the enzymes is unusually limited. Various other phage systems have yielded enzymes active against a number of substrate polysaccharides or at least against acylated and non-acylated polysaccharides with the same carbohydrate structure (e.g. Sutherland, 1971; Thurow et al., 1974). The degree of depolymerization of the substrates is also low, but resembles the effect of the phage-induced endofucosidases acting on colanic acid (Sutherland, 197I). This result may be due to the difficulty that the phage-bound enzymes experience in producing a satisfactory enzyme-substrate complex with the linear chains of the polysaccharide molecules. Irregularities in the substrate composition, such as the loss of acyl groups (from the strain $8 \mathrm{~s}$ polysaccharide), would also lead to failure of the enzyme to hydrolyse the galactosyl-galactose linkages. Such irregularities could arise as a result of polysaccharide purification procedures or through failure of an acyl-transferase to acylate all the appropriate residues during polysaccharide biosynthesis.

The products of both enzymes are tetrasaccharides with D-galactose residues in the reducing and non-reducing terminal positions. The phage-bound enzymes are thus endogalactosidases splitting ... $\alpha$-D-galactosyl-D-galactose... sequences contained in the specific carbohydrate structure of $K$. aerogenes type 8 polysaccharides. The non-reducing terminal galactose is in the $\alpha$-configuration, confirming the structure previously postulated (Sutherland, 1970).

The technical assistance of Mrs J. Chalmers is gratefully acknowledged.

\section{REFERENCES}

Adams, M. H. \& Park, B. H. (I956). An enzyme produced by a phage-host system. II. The properties of the polysaccharide depolymerase. Virology 2, 719-736.

Bessler, W., Freund-Moelbert, E., Knuefermann, C., Rudolph, C., Thurow, H. \& Stirm, S. (1973). A bacteriophage-induced depolymerase (prolysin II) active on Klebsiella KI I capsular polysaccharide. Virology 56, I34-15I.

Bitter, T. \& Muir, H. M. (1962). A modified uronic acid carbazole reaction. Analytical Biochemistry 4, 330-334.

Dudman, W. F. \& WILkInson, J. F. (1956). The composition of the extracellular polysaccharide of Aerobacter-Klebsiella strains. Biochemical Journal 62, 289-295.

EKLUND, C. \& WYsS, O. (I962). Enzyme associated with bacteriophage infection. Journal of Bacteriology $\mathbf{8 4}$, 1209-1215.

Grant, W. M. (1948). Colorimetric micro-determination of formic acid based on reduction to formaldehyde. Analytical Chemistry 20, 267-269.

HeSTRIN S. (1949). The reaction of acetylcholine and other carboxylic acid derivatives with hydroxylamine and its analytical application. Journal of Biological Chemistry 193, 249-261.

Kauffmann, F. \& VaHLNe, G. (1945). The serology of the Klebsiella group. Acta pathologica et microbiologica scandinavica 22, I r9-135.

Lowry, O. H., Rosebrough, N. J., Farr, A. L. \& Randall, R. J. (195I). Protein measurement with the Folin phenol reagent. Journal of Biological Chemistry 193, 265-275.

Sloneker, J. H. \& Orentas, D. G. (1962). Pyruvic acid, a unique component of an exocellular bacterial polysaccharide. Nature, London I94, 478-479. 
STIRM, S. (1968). Escherichia coli $\mathrm{K}$ bacteriophages. I. Isolation and introductory characterization of five Escherichia coli $\mathrm{x}$ bacteriophages. Journal of Virology 2, 1 107-1 114.

STIRM, S. \& FreUnd-MoELBerT, E. (197I). Escherichia coli capsule bacteriophages. II. Morphology. Journal of Virology 8, 330-342.

SUTHERLAND, I. W. (1970). Structure of Klebsiella aerogenes type 8 polysaccharide. Biochemistry, New York 9, $2180-2185$.

SUTHERLAND, I. W. (197I). Enzymic hydrolysis of colanic acid. European Journal of Biochemistry 23, 582-587

SUtherland, I. W. \& Wilkinson, J. F. (1968). The exopolysaccharide of Klebsiella aerogenes A3 (SI) (type 54). Biochemical Journal I10, 749-754.

Thurow, H., NiemanN, H., RudolPh, C. \& Stirm, S. (1974). Host capsule depolymerase activity of bacteriophage particles active on Klebsiella $\mathrm{K} 20$ and $\mathrm{K} 24$ strains. Virology 58, 306-309.

Yurewicz, E. C., Ghalambor, M. A., Duckworth, D. H. \& Heath, E. C. (I97I). Catalytic and molecular properties of a phage-induced capsular polysaccharide depolymerase. Journal of Biological Chemistry 246, 5607-5616. 